\title{
Reduced expression of miR-22 in gastric cancer is related to clinicopathologic characteristics or patient prognosis
}

\author{
Weibin Wang ${ }^{1}$, Fujun $\mathrm{Li}^{i^{*}}$, Yong Zhang ${ }^{2}$, Yanyang $\mathrm{Tu}^{3}$, Qi Yang ${ }^{3}$ and Xingchun Gao ${ }^{3}$
}

\begin{abstract}
Objective: Involvements of microRNA-22 (miR-22) in cancer development have attracted much attention, but its role in tumorigenesis of gastric cancer is still largely unknown. Therefore, the aim of this study was to investigate the expression patterns and clinical implications of miR-22 in gastric cancer.

Methods: Quantitative RT-PCR was performed to evaluate the expression levels of miR-22 in 98 pairs of gastric cancer and normal adjacent mucosa.

Results: Compared with normal adjacent mucosa, miR-22 expression was significantly downregulated in gastric cancer tissues $(P<0.001)$. Of 98 patients with gastric cancer, $58(59.2 \%)$ were placed in the low miR-22 expression group and 40 (40.8\%) were placed in the high miR-22 expression group. In addition, tumors with low miR-22 expression had greater extent of lymph node metastasis $(P=0.02)$ and distant metastasis $(P=0.01)$, and were at a worse stage $(P=0.01)$ than the tumors with high miR-22 expression. Moreover, the gastric cancer patients with low miR-22 expression had shorter overall survival than those with high miR-22 expression $(P=0.03)$. MiR-22, determined by multivariate analysis, was an independent prognostic factor for patients with gastric cancer.

Conclusion: Our data offer the convincing evidence that the reduced expression of miR-22 was significantly associated with malignant development of gastric cancer and may be a novel prognostic marker of this disease. miR-22 might have potentials in the application of cancer therapy for patients with gastric cancer.
\end{abstract}

Keywords: MicroRNA-22, Gastric cancer, Prognosis, Quantitative RT-PCR

\section{Introduction}

Gastric cancer is the fourth most prevalent forms of human cancers and the second leading cause of cancerrelated death in the world, especially in East Asian countries. Its incidence rate is 20 per 100,000 annually [1]. According to its histological subtypes, gastric cancer can be divided into two groups: the intestinal type and the diffuse type. The former is characterized by expansive growth and liver metastasis; whereas the latter is characterized by infiltrative growth and peritoneal dissemination [2-4]. They are both associated with Helicobacter

\footnotetext{
* Correspondence: 18992891737@QQ.com

'Department of General Surgery, The 323th Hospital of PLA, Xi'an 710054, China

Full list of author information is available at the end of the article
}

pylori infection that contributes to more than $80 \%$ of cases [5]. Nowadays, gastrectomy remains the mainstay treatment for gastric cancer, but the prognosis for advanced stage patients is still very poor. The median survival time for patients with gastric cancer is only 6-9 months [6]. In China, the 5-year overall survival rate of patients with gastric cancer is lower than $40 \%$, although recent advances in chemotherapy and surgical techniques [7]. This is primarily attributed to the following reasons: lack of diagnostic markers for early detection, weak prognostic value of histological indicators, limited efficiency of current treatment for advanced disease and lack of molecular markers utilized for targeted therapy [8-10]. Therefore, it is of great significance to make a better understanding of gastric carcinogenesis

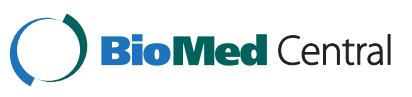


and to identify novel molecular markers for the improvement of clinical management of patients with gastric cancer.

MicroRNAs (miRNAs) are a recently discovered category of small (19 24 nucleotides), non-protein-coding and single-stranded endogenous RNA molecules [11]. miRNAs function as regulators of approximately $60 \%$ protein-coding genes' expression mainly at the posttranscriptional level by binding to the sequences in the $3^{\prime}$ untranslated regions ( $3^{\prime}$-UTR) of their targeted mRNAs resulting in translational repression or gene silencing [12]. As they are involved in regulation of wide array of biological processes including cell proliferation, differentiation, apoptosis, metastasis, angiogenesis and immune response, miRNAs have been considered to be new approaches of tumor biomarkers for early cancer diagnosis and prognosis. They may play roles in the development and progression of cancers similar to those played by oncogenes or tumor suppressor genes. Recent studies have identified a number of miRNAs with aberrant expression in gastric cancer. For example, the comparison of miRNAs deregulated in gastric cancer revealed a significant increase of several tumor-associated miRNAs such as miR-21, -25 and -106a and miRNAs from the miR-17-92 cluster [13]; based on the cluster analyses, eight miRNAs (including miR-100, -143 and -145) were upregulated specifically in diffuse-type, while four miRNA (miR-202, -373, -494 and -498) in intestinal-type gastric cancer [14]. In our previous study, we found that the downregulation of miR-206 was significantly correlated with tumor progression and may be a potent prognostic marker of gastric cancer [15]. According to our literature retrieval, miR-22 has been demonstrated to play important roles in different types of cancer, such as hepatocellular carcinoma, breast cancer, colon cancer, lung cancer, and prostate cancer [16-22]. However, its roles in tumorigenesis of gastric cancer are still unknown. Because of its involvement in several tumors in digestive system (hepatocellular carcinoma and colon cancer), we hypothesized that miR-22 might play a role in gastric cancer. Thus, the aim of the present study was to investigate the expression patterns and clinical implications of miR-22 in gastric cancer.

\section{Materials and methods}

\section{Patients and tissue samples}

This study was approved by the Research Ethics Committee of the 323th Hospital of PLA and Tangdu Hospital of the Forth Military Medical University, China. Written informed consent was obtained from all patients. All specimens were handled and made anonymous according to the ethical and legal standards.

Ninety-eight pairs of gastric cancer and matched normal adjacent mucosa were resected from gastrectomy with lymph node dissection between 1999 and 2007 at Department of General Surgery. These patients with gastric cancer included 62 males and 36 females, ranged in age from 21 to 86 years (mean 63 years). Clinicopathologic findings were based on the criteria of the tumor node metastasis (TNM) classification of the International Union against Cancer [23]. Histopathological types of gastric cancer were classified into two types, intestinal type and diffuse type. The intestinal type was further classified into three differentiated types: well-differentiated (tub1), moderately differentiated (tub2), and papillary differentiated (pap). The diffuse type was classified into two undifferentiated types: diffuse-adherent (por1) and diffuse-scattered (por2). None of these patients underwent endoscopic mucosal resection, palliative resection, or preoperative chemotherapy, or had synchronous or metachronous multiple cancer in other organs. The clinicopathologic features of these patients with gastric cancer were summarized in Table 1.

All patients had follow-up after surgery, with X-ray examination and tumor marker assays (carcinoembryonic antigen and carbohydrate antigen 19-9) performed every 1-3 months, computed tomography performed every 3-6 months, and ultrasonography performed every 6 months. Median follow up period was 38 (range 6 to 139) months for all patients. Overall survival was defined as the period between the time of surgery and death or was censored at the last follow-up. Patients, who died of diseases not directly related to their gastric cancers or due to unexpected events, were excluded from this study.

\section{Quantitative RT-PCR}

In order to detect the expression levels of miR-22 in gastric cancer and matched normal adjacent mucosa, quantitative RT-PCR was performed. Briefly, total RNAs, including the miRNAs, were extracted from 98 primary gastric cancer tissues and matched normal adjacent mucosa using the miRNeasy Mini Kit (Qiagen Inc., Valencia, CA, USA) according to the user's instruction. cDNA was synthesized from $10 \mathrm{ng}$ of total RNA using TaqMan ${ }^{\text {Tx }}$ MicroRNA hsa-miR-22 specific primer (Applied Biosystems) and a TaqMan ${ }^{\mathrm{Tx}}$ MicroRNA Reverse Transcription Kit (Applied Biosystems). RNU6B was used as an internal control. The reverse transcriptase reactions contained $10 \mathrm{ng}$ of total RNAs, $50 \mathrm{nmol} / \mathrm{stem}$-loop RT primer, 1X RT buffer, $0.25 \mathrm{mmol} / \mathrm{L}$ each of dNTP, $3.3 \mathrm{U} / \mu \mathrm{L}$ MultiScribe reverse transcriptase, and $0.2 \mathrm{U} / \mu \mathrm{L}$ RNase inhibitor. The $15 \mu \mathrm{L}$ reaction samples were incubated in GeneAmp PCR System 9700 (Applied Biosystems) for $30 \mathrm{~min}$ at $20^{\circ} \mathrm{C}, 30 \mathrm{~min}$ at $42^{\circ} \mathrm{C}, 5 \mathrm{~min}$ at $95^{\circ} \mathrm{C}$, and then held at $4^{\circ} \mathrm{C}$. Quantitative real-time PCR were performed using ABI StepOne (Applied Biosystems). The PCR conditions were initial denaturation at $95^{\circ} \mathrm{C}$ for 
Table 1 Correlations of miR-22 expression with the clinicopathological features of primary gastric cancer

\begin{tabular}{lllll}
\hline Features & $\begin{array}{l}\text { No. of } \\
\text { cases }\end{array}$ & \multicolumn{2}{l}{ miR-22 expression } & P \\
\cline { 3 - 4 } & & High & Low & \\
\hline Age (years) & 98 & $62.8 \pm 23.2$ & $62.1 \pm 23.9$ & NS \\
Gender & & & & \\
Male & $62(63.3)$ & $25(40.3)$ & $37(59.7)$ & NS \\
Female & $36(36.7)$ & $15(41.7)$ & $21(58.3)$ &
\end{tabular}

Histopathological type

Intestinal type

$\begin{array}{lllll}\text { pap } & 5(5.1) & 2(40.0) & 3(60.0) & \text { NS } \\ \text { tub1 } & 20(20.4) & 9(45.0) & 11(55.0) \\ \text { tub2 } & 25(25.5) & 8(32.0) & 17(68.0)\end{array}$

Diffuse type

$\begin{array}{lllll}\text { por1 } & 15(15.3) & 6(40.0) & 9(60.0) & \text { NS } \\ \text { por2 } & 33(33.7) & 15(45.5) & 18(54.5) & \end{array}$

Tumor depth (pT)

$\begin{array}{lllll}\text { PT1 } & 40(40.8) & 20(50.0) & 20(50.0) & \text { NS } \\ \text { PT2 } & 30(30.6) & 10(33.3) & 20(66.7) & \\ \text { PT3 } & 20(20.4) & 8(40.0) & 12(60.0) \\ \text { PT4 } & 8(8.2) & 2(25.0) & 6(75.0)\end{array}$

Lymph node metastasis $(\mathrm{pN})$

$\begin{array}{llll}\text { pN0 } & 50(51.0) & 27(54.0) & 23(46.0) \\ \text { pN1 } & 20(20.4) & 8(40.0) & 12(60.0) \\ \text { pN2 } & 15(15.3) & 4(26.7) & 11(73.3) \\ \text { pN3 } & 13(13.3) & 1(7.7) & 12(92.3)\end{array}$

Distant metastasis (pM)

\begin{tabular}{|c|c|c|c|c|}
\hline $\mathrm{pMO}$ & $86(87.8)$ & $39(45.3)$ & $47(54.7)$ & 0.01 \\
\hline $\mathrm{pM} 1$ & $12(12.2)$ & $1(8.3)$ & $11(91.7)$ & \\
\hline \multicolumn{5}{|l|}{ pStage } \\
\hline । & $50(51.0)$ & $29(58.0)$ & $21(42.0)$ & \multirow[t]{4}{*}{0.02} \\
\hline$\|$ & $15(15.3)$ & $5(33.3)$ & $10(66.7)$ & \\
\hline III & $20(20.4)$ & $5(25.0)$ & $15(75.0)$ & \\
\hline IV & $13(13.3)$ & $1(7.7)$ & $12(92.3)$ & \\
\hline \multicolumn{4}{|c|}{ Lymphatic invasion } & \\
\hline Negative & $45(45.9)$ & $17(37.8)$ & $28(62.2)$ & \multirow[t]{2}{*}{ NS } \\
\hline Positive & $53(54.1)$ & $23(43.4)$ & $30(56.6)$ & \\
\hline \multicolumn{4}{|c|}{ Venous invasion } & \\
\hline Negative & $68(69.4)$ & $23(33.8)$ & $45(66.2)$ & \multirow[t]{2}{*}{ NS } \\
\hline Positive & $30(30.6)$ & $17(56.7)$ & $13(43.3)$ & \\
\hline \multicolumn{4}{|c|}{ Hematogenous recurrence } & \\
\hline Negative & $78(79.6)$ & $32(41.0)$ & $46(59.0)$ & \multirow[t]{2}{*}{ NS } \\
\hline Positive & $20(20.4)$ & $8(40.0)$ & $12(60.0)$ & \\
\hline
\end{tabular}

Note: 'NS' refers to 'no significant'.
$10 \mathrm{~min}$, followed by 44 cycles of denaturation at $95^{\circ} \mathrm{C}$ for $10 \mathrm{sec}$, annealing at $56^{\circ} \mathrm{C}$ for $10 \mathrm{sec}$, and extension at $60^{\circ} \mathrm{C}$ for $10 \mathrm{sec}$. Analysis was performed by the comparative threshold cycle $(\mathrm{Ct})$ method according to User Bulletin no.2 (Applied Biosystems). Each sample was examined in triplicate and the amounts of the PCR products produced were normalized to RNU6B.

\section{Statistical analysis}

The software of SPSS version12.0 for Windows (SPSS Inc, IL, USA) and SAS 9.1 (SAS Institute, Cary, NC) was used for statistical analysis. Data were expressed as means \pm standard deviation (SD). The differential expression of miR-22 between gastric cancer and matched normal adjacent mucosa was evaluated by paired sample $t$ test. The $X^{2}$ test was used to analyze the relationship between miR-22 expression and the clinicopathologic characteristics. The Kaplan-Meier method was used for survival analysis, and differences in survival were estimated using the log-rank test. Prognostic factors were examined by univariate and multivariate analyses (Cox proportional hazards regression model). Differences were considered statistically significant when $p$ was less than 0.05 .

\section{Results}

Reduced expression of microRNA-22 is associated with advanced clinicopathologic characteristics of patients with gastric cancer

Quantitative RT-PCR was performed to detect the differential expression of miR-22 in 98 pairs of gastric cancer and matched normal adjacent mucosa tissues normalized to RNU6B. As a result, miR-22 expression in gastric cancer was significantly lower than that in normal adjacent mucosa (mean $\pm \mathrm{SD}$ : $2.1 \pm 1.2$ vs. $3.6 \pm 1.3, \mathrm{P}<0.001$, Figure 1).

The 98 patients with gastric cancer were classified into two groups according to the median expression level of miR-22 (2.2, normalized to RNU6B) as determined by quantitative RT-PCR. Of 98 patients with gastric cancer, $58(59.2 \%)$ were placed in the low miR-22 expression group and $40(40.8 \%)$ were placed in the high miR-22 expression group. The association between clinicopathologic features and miR-22 expression was summarized in Table 1. Tumors with low miR-22 expression had greater extent of lymph node metastasis $(P=0.02)$ and distant metastasis $(P=0.01)$, and were at a worse stage $(P=0.01)$ than the tumors with high miR-22 expression.

\section{Reduced expression of microRNA-22 confers poor} prognosis in patients with gastric cancer

All 98 patients with gastric cancer received follow-up after surgery. No patient died of postoperative complications within 30 days at the beginning of the study period. 


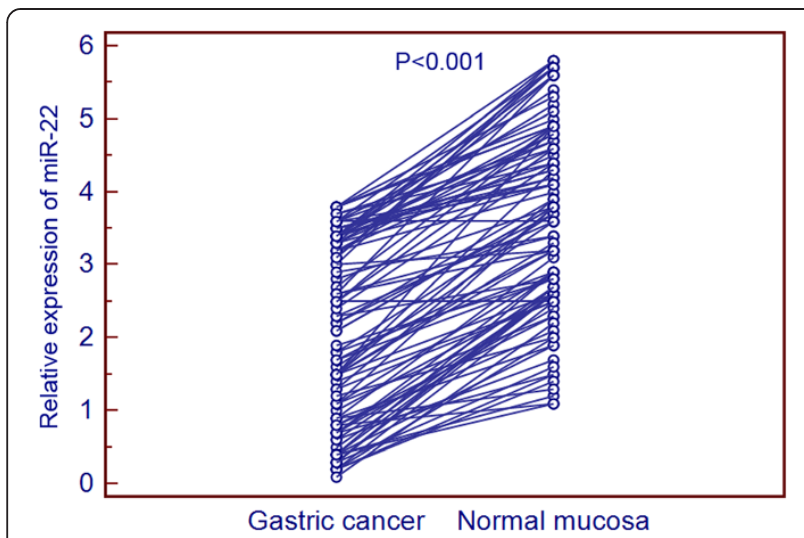

Figure 1 Expression levels of miR-22 in 98 pairs of gastric cancer tissues and normal adjacent gastric mucosa. miR-22 expression was significantly downregulated in gastric cancer tissues when compared with normal adjacent mucosa $(P<0.001)$.

The 5-year survival rate of patients with tumors with high miR-22 expression was $82.5 \%$ (33/40), whereas the rate for patients with low miR-22 expression was $58.6 \%$ $(34 / 58)$. Thus, the gastric cancer patients with low miR22 expression had shorter overall survival than those with high miR-22 expression ( $\mathrm{P}=0.03$, Figure 2$)$.

The univariate and multivariate analyses were also performed to identify factors related to patient prognosis. As shown in Table 2, the univariate analysis showed that the depth of tumor invasion $(\mathrm{P}=0.006)$, lymph node metastasis $(P=0.001)$, venous invasion $(P=0.03)$, tumor stage $(P=0.03)$ and miR-22 expression $(P=0.03)$ were significantly related to postoperative survival. Moreover, the multivariate regression analysis indicated that the depth of invasion $(\mathrm{P}=0.01)$, lymph node metastasis $(\mathrm{P}=0.01)$ and $\mathrm{miR}-22$ expression $(\mathrm{P}=0.04)$ were independent prognostic factors for patients with gastric cancer.

\section{Discussion}

Accumulating evidences have demonstrated that miRNAs play important roles in various physiological and pathological processes, and have a robust association with carcinogenesis. miRNAs have been considered to be novel biomarkers for various cancers. Among human miRNAs, miR-22 is located at a fragile cancer-relevant genomic region in chromosome 17 (17p13.3), and is mapped to an exon of the C17orf91 gene [24]. This miRNA plays unique roles in specific cell types. For example, it regulates PPARalpha and BMP7 signaling pathways in human chondrocytes [25], and the differentiation of a monocyte cell line [26]. Recent studies have demonstrated that miR-22 is deregulated in many types of cancers and is involved in various cellular processes related to carcinogenesis, including cell growth, apoptosis, motility, and cell cycle. Zhang et al. [16] indicated that miR-22 was downregulated in hepatocellular carcinoma and had considerable

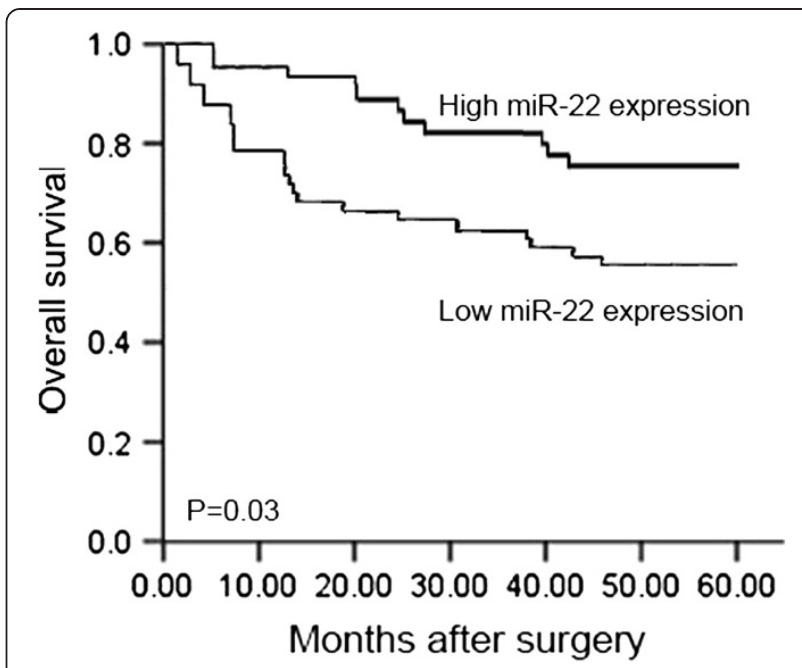

Figure 2 Postoperative 5-year survival curves of patients according to the expression of miR-22. The gastric cancer patients with low miR-22 expression had shorter overall survival than those with high miR-22 expression $(P=0.03)$.

potential in identification of the prognosis; Xiong et al. [17] found that miR-22 was frequently downregulated in $\mathrm{ER} \alpha$-positive human breast cancer cell lines and clinical samples; Li et al. [18] identified miR-22 as a potential metastasis-inhibitor in ovarian cancer; Yamakuchi et al. [19] found that miR-22 expression in human colon cancer was lower than in normal colon tissue, and it might have an anti-angiogenic effect in this cancer; Ling et al. [20] observed the downregulation of miR-22 in lung cancer tissues and lung cancer cell lines, and also suggested that miR-22 might exhibit excellent anti-lung cancer activity in vitro and in vivo. All these studies suggest that miR-22 may act as a tumor suppressor. In contrast, Poliseno et al.

Table 2 Univariate and multivariate analyses of prognostic factors in gastric cancer

\begin{tabular}{|c|c|c|c|c|}
\hline $\begin{array}{l}\text { Independent } \\
\text { factors }\end{array}$ & $\begin{array}{l}\text { Univariate } \\
\mathrm{P}\end{array}$ & $\begin{array}{l}\text { Multivariate } \\
\mathrm{P}\end{array}$ & $\begin{array}{l}\text { Hazard } \\
\text { ratio }\end{array}$ & $\begin{array}{l}95 \% \\
\text { confidence } \\
\text { interval }\end{array}$ \\
\hline \multicolumn{5}{|l|}{ Tumor depth (pT) } \\
\hline $\begin{array}{l}\text { pT1 and pT2/pT3 } \\
\text { and pT4 }\end{array}$ & 0.006 & 0.01 & 3.8 & $1.0 \sim 7.2$ \\
\hline \multicolumn{5}{|c|}{ Lymph node metastasis (pN) } \\
\hline Negative/positive & 0.001 & 0.01 & 4.1 & $1.2 \sim 8.9$ \\
\hline \multicolumn{5}{|l|}{ Venous invasion } \\
\hline Negative/positive & 0.03 & NS & 1.8 & $0.5 \sim 3.1$ \\
\hline \multicolumn{5}{|l|}{ pStage } \\
\hline $\begin{array}{l}\text { I and II and III } \\
\text { and IV }\end{array}$ & 0.03 & NS & 1.2 & $0.09-2.3$ \\
\hline \multicolumn{5}{|l|}{ miR-22 expression } \\
\hline Negative/positive & 0.03 & 0.04 & 2.2 & $0.6 \sim 5.2$ \\
\hline
\end{tabular}

Note: 'NS' refers to 'no significant'. 
[21] showed that miR-22 was aberrantly overexpressed in human prostate cancer; Liu et al. [22] have reported that miR-22 might act as a micro-oncogene in transformed human bronchial epithelial cells induced by anti-BPDE. These controversial findings of miR-22 in cancer development suggest the diverse roles of miR-22 in different types of cancer. In the present study, we confirmed that miR-22 expression was frequently reduced in gastric cancer tissues than in their normal adjacent mucosa. Moreover, the downregulation of miR-22 was found to be more frequently occurred in gastric cancer tissues with great extent of lymph node and distant metastases, and with an advanced stage.

To our knowledge, the invasion and metastasis of tumor cells are major causes of mortality in cancer patients. Therefore, the potential value of miR-22 as a prognostic marker is of interest. Yet, there has been only one study that has attempted to identify the prognostic value of miR-22 for hepatocellular carcinoma. Using 160 primary hepatocellular carcinoma cases, Zhang et al. [16] found that low miR-22 expression correlated with poor overall survival. In line with this finding, we analyzed not only the Kaplan-Meier survival curve but also applied Cox multivariate analysis to clarify the prognostic value of miR-22 in gastric cancer. Notably, we demonstrated that low miR-22 expression in gastric cancer tissues significantly correlated with poorer overall survival. Furthermore, in Cox multivariate analysis, miR-22 expression in gastric cancer tissues showed a significant association with overall survival.

In conclusion, our data offer the convincing evidence that the reduced expression of miR-22 was significantly associated with malignant development of gastric cancer and may be a novel prognostic marker of this disease. miR-22 might have potentials in the application of cancer therapy for patients with gastric cancer. However, our study is limited by the number of study cases with relatively small subgroups. Further investigations with a larger number of cases would allow us to evaluate miR-22 in a variety of clinical settings and help us better understand its unique role in cancer progression.

\section{Competing interests}

The authors declare that they have no competing interests.

\section{Authors' contributions}

WW and FL designed the study, carried out the experiments and drafted the manuscript; YZ, YT, QY and XG participated in the experiments and data analysis. All authors read and approved the final manuscript.

\section{Author details}

'Department of General Surgery, The 323th Hospital of PLA, Xi'an 710054

China. ${ }^{2}$ Authorities outpatient Department of Lanzhou Military region, Lanzhou 730000, China. ${ }^{3}$ Department of Experimental Surgery, Tangdu Hospital, Fourth Military Medical University, Xi'an City 710038, P.R. China.
Received: 25 April 2013 Accepted: 3 June 2013

Published: 21 June 2013

\section{References}

1. Siegel R, Naishadham D, Jemal A: Cancer statistics, 2013. CA Cancer J Clin 2013, 63:11-30.

2. Ye YW, Dong RZ, Zhou Y, Du CY, Wang CM, Fu H, Shi YQ: Prognostic analysis of familial gastric cancer in Chinese population. J Surg Oncol 2011, 104:76-82.

3. Shan L, Ying J, Lu N: HER2 expression and relevant clinicopathological features in gastric and gastroesophageal junction adenocarcinoma in a Chinese population. Diagn Pathol 2013, 8:76.

4. Liu X, Xiong H, Li J, He Y, Yuan X: Correlation of hK6 expression with tumor recurrence and prognosis in advanced gastric cancer. Diagn Pathol 2013, 8:62.

5. Wu WK, Lee CW, Cho CH, Fan D, Wu K, Yu J, Sung JJ: MicroRNA dysregulation in gastric cancer: a new player enters the game. Oncogene 2010, 29:5761-5771.

6. Jemal A, Bray F, Center MM, Ferlay J, Ward E, Forman D: Global cancer statistics. CA Cancer J Clin 2011, 61:69-90.

7. Zhang YZ, Zhang LH, Gao Y, Li CH, Jia SQ, Liu N, Cheng F, Niu DY, Cho WC, Ji JF, Zeng CQ: Discovery and validation of prognostic markers in gastric cancer by genome-wide expression profiling. World J Gastroenterol 2011, 17:1710-1717.

8. Jia YF, Xiao DJ, Ma XL, Song YY, Hu R, Kong Y, Zheng Y, Han SY, Hong RL, Wang YS: Differentiated embryonic chondrocyte-expressed gene 1 is associated with hypoxia-inducible factor $1 a$ and Ki67 in human gastric cancer. Diagn Pathol 2013, 8:37.

9. Jin J, Jin T, Quan M, Piao Y, Lin Z: Ezrin overexpression predicts the poor prognosis of gastric adenocarcinoma. Diagn Pathol 2012, 7:135.

10. Sotoudeh K, Hashemi F, Madjd Z, Sadeghipour A, Molanaei S, Kalantary E: The clinicopathologic association of c-MET overexpression in Iranian gastric carcinomas; an immunohistochemical study of tissue microarrays. Diagn Pathol 2012, 7:57.

11. Doench JG, Sharp PA: Specificity of microRNA target selection in translational repression. Genes Dev 2004, 18:504-511.

12. Esquela-Kerscher A, Slack FJ: Oncomirs-microRNAs with a role in cancer. Nat Rev Cancer 2006, 6:259-269.

13. Link A, Kupcinskas J, Wex T, Malfertheiner P: Macro-role of microRNA in gastric cancer. Dig Dis 2012, 30:255-267.

14. Song MY, Pan KF, Su HJ, Zhang L, Ma JL, Li JY, Yuasa Y, Kang D, Kim YS, You WC: Identification of serum microRNAs as novel non-invasive biomarkers for early detection of gastric cancer. PLoS One 2012, 7:e33608.

15. Yang Q, Zhang C, Huang B, Li HY, Zhang R, Huang YX, Wang JJ: Downregulation of microRNA-206 is a Potent Prognostic Marker for Patients with Gastric Cancer. Eur J Gastroenterol Hepatol 2013. In press.

16. Zhang J, Yang Y, Yang T, Liu Y, Li A, Fu S, Wu M, Pan Z, Zhou W: MicroRNA22, downregulated in hepatocellular carcinoma and correlated with prognosis, suppresses cell proliferation and tumourigenicity. Br J Cancer 2010, 103:1215-1220.

17. Xiong J, Yu D, Wei N, Fu H, Cai T, Huang Y, Wu C, Zheng X, Du Q, Lin D, Liang Z: An estrogen receptor alpha suppressor, microRNA-22, is downregulated in estrogen receptor alpha-positive human breast cancer cell lines and clinical samples. FEBS J 2010, 277:1684-1694.

18. Li J, Liang S, Yu H, Zhang J, Ma D, Lu X: An inhibitory effect of miR-22 on cell migration and invasion in ovarian cancer. Gynecol Oncol 2010, 119:543-548.

19. Yamakuchi M, Yagi S, Ito T, Lowenstein CJ: MicroRNA-22 regulates hypoxia signaling in colon cancer cells. PLoS One 2011, 6:e20291.

20. Ling B, Wang GX, Long G, Qiu JH, Hu ZL: Tumor suppressor miR-22 suppresses lung cancer cell progression through post-transcriptional regulation of ErbB3. J Cancer Res Clin Oncol 2012, 138:1355-1361.

21. Poliseno L, Salmena L, Riccardi L, Fornari A, Song MS, Hobbs RM, Sportoletti P, Varmeh S, Egia A, Fedele G, Rameh L, Loda M, Pandolfi PP: Identification of the miR-106b 25 microRNA cluster as a proto-oncogenic PTEN-targeting intron that cooperates with its host gene MCM7 in transformation. Sci Signal 2010, 3:ra29.

22. Liu $L$, Jiang $Y$, Zhang $H$, Greenlee $A R$, Yu R, Yang Q: MiR-22 functions as a micro-oncogene in transformed human bronchial epithelial cells induced by anti-benzo[a]pyrene-7,8-diol-9,10-epoxide. Toxicol In Vitro 2010, 24:1168-1175. 
23. Sobin LH, Wittekind C: TNM classification of malignant tumours. 6th edition. New York: Wiley, International Union Against Cancer; 2002:121-126.

24. Gurha P, Abreu-Goodger C, Wang T, Ramirez MO, Drumond AL, van Dongen S, Chen Y, Bartonicek N, Enright AJ, Lee B, Kelm RJ Jr, Reddy AK, Taffet GE, Bradley A, Wehrens XH, Entman ML, Rodriguez A: Targeted deletion of microRNA-22 promotes stress-induced cardiac dilation and contractile dysfunction. Circulation 2012, 125:2751-2761.

25. Iliopoulos D, Malizos KN, Oikonomou P, Tsezou A: Integrative microRNA and proteomic approaches identify novel osteoarthritis genes and their collaborative metabolic and inflammatory networks. PLoS One 2008, 3:e3740.

26. Ting Y, Medina DJ, Strair RK, Schaar DG: Differentiation-associated miR-22 represses Max expression and inhibits cell cycle progression. Biochem Biophys Res Commun 2010, 394:606-611.

doi:10.1186/1746-1596-8-102

Cite this article as: Wang et al:: Reduced expression of miR-22 in gastric cancer is related to clinicopathologic characteristics or patient prognosis. Diagnostic Pathology 2013 8:102.

\section{Submit your next manuscript to BioMed Central and take full advantage of:}

- Convenient online submission

- Thorough peer review

- No space constraints or color figure charges

- Immediate publication on acceptance

- Inclusion in PubMed, CAS, Scopus and Google Scholar

- Research which is freely available for redistribution 